\title{
Artificially deformed crania from the Hun-Germanic Period (5th-6th century AD) in northeastern Hungary: historical and morphological analysis
}

\author{
Mónika Molnár, M.S., ${ }^{1}$ István János, Ph.D., ${ }^{2}$ László Szücs, M.S., ${ }^{3}$ \\ and László Szathmáry, C.Sc. ${ }^{3}$ \\ ${ }^{1}$ Faculty of Health, University of Debrecen, Nyíregyháza; ${ }^{2}$ Institute of Environmental Science, College of \\ Nyíregyháza, Nyíregyháza; and ${ }^{3}$ Department of Evolutionary Zoology and Human Biology, University of \\ Debrecen, Hungary
}

\begin{abstract}
From an anthropological point of view, artificial deformation of the cranial shape in newborns is one of the most interesting human customs, which has been recorded in all continents and in different cultures. However, the main goals of this procedure were basically the same everywhere; that is, to distinguish certain groups of people from others and to indicate the social status of individuals. In the Carpathian Basin all artificially deformed skulls are dated to the late Iron Age, especially to the early Migration Period. The authors examined 9 artificially deformed skulls from the Hun-Germanic Period (5th-6th century AD) excavated from two cemeteries in the northeastern part of the Great Hungarian Plain (Hungary). The extent and the type of the deformation as well as the technique were determined in each case. The authors also attempt to shed light on the probable origin and the historical context of the custom practiced in the Carpathian Basin (Hungary), relying on the anthropological and historical literature on the Hun-Germanic and preceding periods. It seems possible that this custom, which is associated with the finds in the Carpathian Basin, first appeared in the Kalmykia steppe, later in the Crimea, from where it spread to Central and Western Europe by way of the Hun migration. Neither the cranial find described presently nor the special literature on the subject furnish convincing evidence that the cranial deformation resulted in any chronic neurological disorder. (http://thejns.org/doi/abs/10.3171/2014.1.FOCUS13466)
\end{abstract}

\section{Key Words • Hun-Germanic Period • artificially deformed skull • physical anthropology}

$\mathrm{M}$ ODIFICATIONS of parts of the body which cause permanent alteration in the shape (such as body piercing, tattooing, mutilation, circumcision, clitoridectomy, foot binding, and so on) have been practiced from the beginning of human history. The main goals of these customs must have been basically the same everywhere; that is, to distinguish certain groups of people from others and to indicate the social status of individuals.

The various types of artificial skeletal modifications were widespread all over the world in the past, and two of them in particular-the intentional deformation of the cranium and the practice of trephination - are of great paleoneurosurgical and paleopathological importance. $5,10,29$

From an anthropological point of view, artificial cranial deformation of infants seems to be one of the most interesting human customs, which has been recorded in all continents and in different cultures. Intentionally deformed skulls have been described in written sources from the earliest times of appearance. ${ }^{4,7,17}$ According to the current state of knowledge, this custom probably appeared independently in different regions of the world..$^{28-30}$ Artificially deformed skulls dating back to as early as the
Late Paleolithic Period have been recorded. ${ }^{8,9,37}$ The alteration of head shape, which was widely favored because of the plasticity of the cranium of newborn infants, was performed with the help of a strong pressure exerted on the head from the 1st day of life to approximately 3 years of age.

The origin and the culture of the peoples who lived in the Carpathian Basin in the Hun-Germanic Period (5th6th century AD), are still a matter of debate. ${ }^{20}$ However, it has been pointed out that the custom of artificial cranial deformation appeared with all these peoples; that is, with the Sarmatian, Alan, Gothic, Gepidic, and Hun populations equally.

In the present work, 9 artificially deformed skulls excavated from two contemporaneous cemeteries dated to the Migration (Hun-Germanic) Period (5th-6th century) in northeastern Hungary were analyzed from a physical anthropological point of view. The basic aims of this study were to attempt to shed light on the type and the extent of the deformation as well as to determine the technique used for head shaping in each case. Additionally, the possible origin and ethnic context of the intentional deformation that appeared in the Carpathian Basin are 
discussed, alluding to the results of anthropological, archaeological, and historical research. Finally, the possible neurological disorders emerging from the change of the head shape are also referred to.

\section{Short Review of the History of the Hun-Germanic Period (AD 420-455 and 455-567) and of the Most Significant Finds of Intentionally Deformed Crania in the Carpathian Basin (Hungary)}

In the 1st millennium $\mathrm{AD}$, besides the Romans and the nomadic populations of Eastern origin (namely Alans, Sarmatians, Huns, Avars, and ancient Hungarian tribes), the Germanic peoples (that is, Gepids, Ostrogoths, and Langobards) played a key role in the history of the Carpathian Basin. ${ }^{12}$

Before the appearance of the Huns in the Great Hungarian Plain - as the region is called today-the Germanic tribes attempted to enter the territory of the Roman Empire, which might have provided prosperity and security for them. The province of Pannonia lay west of the River Danube in the Carpathian Basin. In the 3rd century, the importance of the Sarmatian land, the Barbarian territory, increased for the Romans as a defense zone against eastern assaults because they had to confront Gothic attacks from the east. ${ }^{35}$ In 375, the Huns crossed the River Volga and forced the fleeing peoples westward. At the end of the 4th century, the united Hun-Alan-Gothic troops defeated the Roman legions in a battle of great consequence near Hadrianopolis (Edirne, Turkey) and Rome was compelled to allow the victorious peoples to move westward and settle down in Pannonia Province. This, then, induced a population movement of peoples of Turkish, Iranian, and Germanic origin, which grew to such large dimensions as had rarely occurred in the history of Eurasia. In the Carpathian Basin, uninterrupted fighting in the frontier zone of the Roman Empire resulted in the collapse of the Sarmatian defense line. The invasion of the Huns from the East drove a lot of barbaric tribes such as Goths, Scirians, Vandals, Alans, Suebians, and Gepids across the Great Hungarian Plain. On December 31, 406, the Vandal, Alan, and Quad troops crossed the Rhine River. This date is regarded as the actual beginning of the Migration Period for the West. The Huns occupied the Carpathian Basin in a few years, and from 420 they established the center of their empire east of the River Tisza (in present-day Hungary). From this area they led campaigns against different regions of Europe. In 453 Attila, the leader of the Hun Empire, suddenly died, whereupon the dependent peoples including mainly Germanic tribes rebelled against the Huns and expelled them from the Carpathian Basin within approximately 2 years. The crash of the Hun Empire was efficiently helped by the conflict between Attila's sons for the throne. ${ }^{36}$

After 455, closing the Hun Period, the conquering peoples of Germanic origin took over the control of Central and Western Europe as well as Italy. The region of the Great Hungarian Plain was dominated by the Gepidic tribes, which founded a kingdom in the Tisza region and Transylvania, supported by the Byzantine Empire. At the same time, the western part of the Carpathian Basin (called Transdanubia at present) was occupied by the Ostrogoths (456-471) for 15 years, whereas in the first half of the 6th century the Langobards, a people with western Germanic roots, had control over the area. The Langobards and Gepids lived in peace until 552. That year, however, the alliance of the Gepids and the Byzantines forced the Langobards to ask the Iranian-rooted Avars for help. The decisive battle in 567 resulted in the demolition of the Gepid kingdom. The Avars, who became stronger and stronger, conquered the whole Carpathian Basin, which meant the end of the independent Central European history of the Germanic peoples. The Langobards, the former allies of Avars, had to leave the Carpathian Basin and escaped to Northern Italy in 568. Large numbers of Gepids remained in the central and eastern areas of the Plain (in present-day Hungary and Romania); they even fought side by side with the Avars against Byzantium, but their own country no longer existed. All these events of human migration shook the stability of the Roman Empire and induced a fast development of the outlines of European states-to-be. ${ }^{12}$

In the history of the Migration Period, the territory of Hungary is of considerable archaeological and historical importance, which unequivocally exceeds the political and geographical boundaries. Thanks to its favorable geographical location, the Carpathian Basin became a significant buffer area, as the annals of history reviewed above demonstrate..$^{17,23,35}$

The frequent appearance of artificial cranial deformation in Europe and in the Carpathian Basin can be attributed to the movements of the Huns, who flowed into Europe in the 4th-5th century. As discussed above, peoples of different (mainly Germanic) origin were pushed westward by the Huns, and these populations may already have adopted the custom of cranial deformation from the Huns as early as the 2nd-3rd century. Archeologists have problems assigning graves and skeletons to the Huns for several reasons. On the one hand, except for the gravesites of the aristocracy, which abounded with grave goods, the commoners' graves were poorly or not furnished. On the other hand, the custom of cremation burial was also widely applied by all these populations. Just as the graves of the Huns can rarely be distinguished from the graves of the Gepids or Ostrogoths, neither can the Hun Period be marked off from the Germanic Era. That is why the two eras are jointly defined as the Hun-Germanic Period. However, the custom of artificial cranial deformation survived among the Germanic populations remaining in the area of the Avar Empire until the early 7 th century. ${ }^{17}$

In the Carpathian Basin, including the present-day Hungary, approximately 200 skulls are regarded as artificially deformed. First Lenhossék ${ }^{21}$ and Török ${ }^{33}$ reported on intentionally deformed skulls in their earliest papers at the end of the 19th century. With 20 intentionally deformed skulls, the site of Kiszombor-B, described by Bartucz $^{3}$ in 1936 and attributed to the Gepidic population, is of great scientific importance. From the second half of the 20th century, Nemeskéri, ${ }^{24}$ Kiszely, ${ }^{18}$ and Lipták ${ }^{22}$ dealt with this subject substantially. In the last decades, significant finds became known from Fenékpuszta and Szegvár-Oromdúlő; sites dated back to the Hun-German- 


\section{Artificial cranial deformations from the Hun-Germanic Period}

ic and the Avar Periods, respectively. ${ }^{13,27}$ From the cemetery of Mözs, which was also dated to the Hun-Germanic Period, approximately 50 artificially deformed skulls came to light. All of the finds excavated in the Carpathian Basin were dated from the late Iron Age and the early Migration Period, from the end of the 4th century to the beginning of the 7th century.

\section{Methods \\ Study Sites and Samples}

The human skeletal finds examined were excavated in two cemeteries, namely Ároktő Csík-gát and Nyíregyháza M3, 36/c, in the Great Hungarian Plain in northeastern Hungary (Fig. 1). The two cemeteries were located relatively close to each other, at a distance of approximately 70 air $\mathrm{km}$.

The excavation in the burial site of Ároktő Csík-gát, where 250 graves with 249 individuals became known, was conducted between 1996 and 2000. The graves were dated from the Hun-Germanic Period (5th-6th century $\mathrm{AD})$ at the earliest to the age of the Hungarian conquest (9th-10th century AD) at the latest. Three of the 20 individuals whose remains dated back to the Hun-Germanic Period were artificially deformed. ${ }^{19}$

The skeletal finds at the Nyíregyháza-Rozsrétszőlő site, which was named after the section of the motorway M3 as "M3, 36/c," were excavated in 2005. During the archaeological excavation, a 5th-century cemetery with 34 graves came to light in addition to a settlement from the Late Bronze Age and another one from the age of the Roman Empire. ${ }^{2}$ Archeological and historical evidence equally suggested that the graves belonged to the pagan Gepids or Huns consisting of various ethnic groups.

\section{Methods Used for Morphological Analysis of the Artificially Deformed Crania}

The morphological sex determination of the individuals was carried out using the recommendations suggested by Éry et al. ${ }^{11}$ Twenty-three sex traits on the cranium and the postcranial skeleton were taken into account.

The determination of age at death in the case of the juvenile individuals was based on the degree of epiphy-

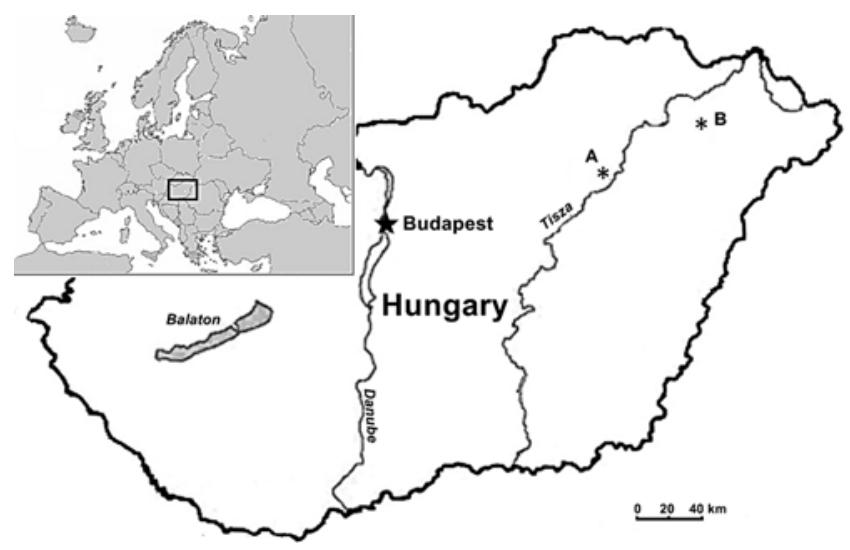

FIG. 1. Maps showing the location of the sites described in this study. A = Ároktő Csík-gát; $B$ = Nyíregyháza M3, 36/c. seal union, the ossification status of bones, and the diaphysis length of long bones, following the instructions proposed by Johnston ${ }^{15}$ as well as Stloukal and Hanáková. ${ }^{32}$ For the adult skeletons, the combined methods elaborated by Nemeskéri et al., ${ }^{25}$ Acsádi and Nemeskéri, ${ }^{1}$ as well as Sjøvold ${ }^{31}$ were applied.

The degree of deformation was calculated and classified using the index developed by Oetteking ${ }^{26}$ with Ginzburg and Žirov ${ }^{14}$ (OGŽ index; Table 1). The index is calculated according to the following formula: OGŽ index $=$ basion - antibasion distance $\times 100 /$ glabella - inion distance.

The definition for the deformation types is not consistent in the scientific literature, which causes some uncertainty and calls attention to the use of the nomenclature. To determine the types of cranial deformation, the classification of Dembo and Imbelloni ${ }^{7}$ (see also Cocilovo et al. ${ }^{6}$ ), which is one of the synthetic works referred to most frequently in physical anthropology, was applied. In this way, 4 main types of cranial deformities could be distinguished, which are as follows.

\section{Types of Deformation}

Tabular Oblique. Crania with tabular oblique deformation are characterized by an oblique plane in the iniac region on the occipital bone as well as a depressed and strongly inclined frontal bone. In most cases, the cranial length and width increase considerably. These modifications are carried out by anterior-posterior compression by hard and rigid tools. The general shape axis is dislocated posteriorly, above the Frankfort horizontal plane.

Tabular Erect. In this case, the frontal bone of the cranium may be plated or slightly altered. Individuals of this type tend to have a net vertical plane in the lambda region of the occipital bone, which is frequently parallel to the basion-bregma height. It can be observed that the height and the width of the cranium are increased as a result of the anterior-posterior compression of the skull by firm and rigid elements (for example, pads, cradle board, or tablets). Due to the intervention, the neurocranium alters to a high extent while the splanchnocranium changes to a slight extent. The general shape axis is approximately orthogonal in relation to the Frankfort horizontal plane.

Circular Oblique. Specimens of this deformation type are characterized by either a slight or pronounced flattening of the frontal and occipital bones in the cranial vault. In the area of higher-intensity deformation, one can often find a transverse groove running straight to the general shape axis. Incidentally, there is a marked inclination backward in relation to the Frankfort horizontal plane.

TABLE 1: The extent of the cranial modification according to the OGž index

\begin{tabular}{cl}
\hline Value of OGž Index & \multicolumn{1}{c}{ Extent of Deformation } \\
\hline$<90$ & slightly deformed \\
$90-100$ & medium deformed (macrocranic) \\
$>100$ & heavily deformed (hypermacrocranic) \\
\hline
\end{tabular}


The normal development of width and height is restricted but compensatory growth can usually be noted, mostly in longitudinal vault expansion. The circular oblique form can be obtained as a result of the application of more flexible tools (for example, bandages, bands, tapes, and headdress).

Circular Erect. Crania of this type can demonstrate either a slight or a pronounced flattening of the frontal bone. Furthermore, a transverse curved groove can often be observed on the frontal bone, which proceeds on the walls of the temporal bones, ending around the lambda region on the occipital bone. The development of the skull is restricted in width and length, while a remarkable growth in height can be noticed. The expansion in the obelion area can also often be detected. For the deformation procedure, the same devices are used as for the circular oblique type (especially more flexible tapes and bands).

\section{Results}

The aggregate data of the crania are presented in Table 2. According to the taxonomic analysis, all 9 of the skulls indicated the main characteristics of the Europid "great race." None of them showed any Mongoloid features, which also appeared in the ancient population history of the Carpathian Basin, especially within the Huns, Avars, and ancient Hungarians. Due to the combination of different race characteristics within the Europid great race, more precise determination was not possible.

In the case of the Ároktő Csík-gát site, the age at death was exactly determined because the juvenile individuals could be analyzed on the basis of the degree of epiphyseal union of their long bones. In contrast, there were 4 skeletons (Nos. 40, 42, 49, and 220) in the cemetery of Nyíregyháza M3, 36/c, for which the age at death could only be given in very wide intervals due to the lack of age indicators except for the endocranial suture closure. Besides the traces of the artificial intervention, no other pathological changes could be observed in the skulls. The possible causes of death might not have been connected with the intentional cranial deformation practices. The descriptions of the 9 artificially deformed skulls are given with the name of sites and grave numbers indicated as follows.
Ároktő Csík-gát, No. 166

This skull is that of a 21- to 25-year-old man (Fig. 2). Whereas the neurocranium could be well analyzed, the splanchnocranium is missing. Due to the intervention, the tuber parietale on both sides shifted slightly toward the sutura sagittalis and the occipital bone became precipitous in the posterior third of the sutura sagittalis. A 40-mm-wide bandage, which may have been the main bandage encircling the cranium, can be assumed to have run above the tuber frontale and around the lambda region. It is very probable that another bandage was also used during the modification, which left a shallow groove right behind the bregma region on the calvaria as well as on the occipital bone running on the sutura squamosa. In this case the OGŽ index could not be determined due to the lack of the cranial base; however, a moderate deformation (macrocranic) can be suggested. The type of the deformation shows an obvious circular erect form.

\section{Ároktő Csík-gát, No. 166/a}

This cranium could not be completely analyzed either, but the neurocranial deformities could be well observed (Fig. 2). This skull of a 21- to 25-year-old woman was artificially deformed in the same way (although more extensively) as is described with the individual in Grave No. 166. The value of the OGŽ index is 105.6, which represents a heavy cranial modification (hypermacrocranic). This skull also denotes an unambiguous circular erect form of artificial deformation, which was achieved using a simple bandaging technique.

\section{Ároktő Csík-gát, No. 168}

This cranium with a typical erect deformation is that of a 15- to 17-year-old female (Fig. 2). The head was considerably deformed with one 30- to 40-mm-wide, circular bandage, which probably ran right above the lambda region and along the squamosal suture on the parietal bones as well as above the frontal tubers on the frontal bone. According to the OGŽ index (101.3), the cranium was heavily deformed (hypermacrocranic).

Nyíregyháza M3, 36/c, No. 40

This complete skull of a 40 - to 80 -year-old man was

TABLE 2: Aggregate data of the 9 examined individuals with deformed skulls*

\begin{tabular}{|cclccc}
\hline Site/Sample & Grave No. & Sex & Age at Death (yrs) & OGž Index & Type of Deformation \\
\hline Ároktő Csík-gát & 166 & male & $21-25$ & - & circular erect \\
\hline Ároktő Csík-gát & $166 / a$ & female & $21-25$ & 105.60 & circular erect \\
\hline Ároktö Csík-gát & 168 & female & $15-17$ & 101.30 & circular erect \\
\hline Nyíregyháza M3, 36/c & 40 & male & $40-80$ & 88.30 & circular oblique \\
\hline Nyíregyháza M3, 36/c & 42 & male & $40-80$ & 82.35 & circular oblique \\
\hline Nyíregyháza M3, 36/c & 49 & female & $30-60$ & 84.56 & circular erect \\
\hline Nyíregyháza M3, 36/c & 50 & male & $37-46$ & 90.85 & tabular oblique \\
\hline Nyíregyháza M3, 36/c & 61 & female & $35-55$ & 88.67 & tabular erect \\
\hline Nyíregyháza M3, 36/c & 220 & female & $40-80$ & 92.63 & tabular oblique \\
\hline
\end{tabular}

* $-=$ could not be measured because of the absence of splanchnocranium. 


\section{Artificial cranial deformations from the Hun-Germanic Period}
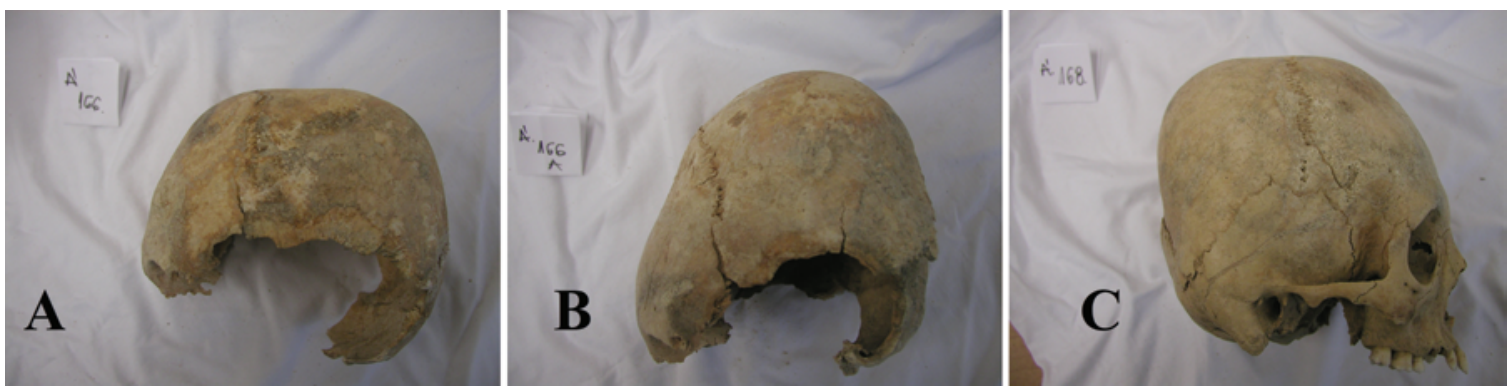

FIG. 2. Photographs showing artificially deformed crania from the Ároktő Csík-gát site: Grave No. 166 (A); No. 166/a (B); No. 168 (C)

presumably modified using one bandage. The occipital bone is markedly precipitous (Fig. 3). The OGŽ index (88.3) refers to a slightly deformed cranium. The skull deformation is classified as a circular oblique type, but the use of some rigid element on the frontal and occipital bones can also be presumed.

Nyíregyháza M3, 36/c, No. 42

This male cranium shows a close morphological similarity to the skull from Grave No. 40 (Fig. 3), and the technique applied in the artificial modification is also analogous (including the use of one bandage). The calculated age at death is $40-80$ years. The OGZ index represents a slightly lower value (82.35) than that in the former individual, so this skull is also slightly deformed. The type of deformation is circular oblique.

Nyíregyháza M3, 36/c, No. 49

The skull of this 30- to 60-year-old woman (Fig. 3) was presumably deformed using a sort of rigid plate that was depressed with a bandage above the frontal eminences on the frontal bone (flat area with a $30-$ to $35-\mathrm{mm}$ diameter). The traces of the bandage are also apparent at the lower third on both temporal bones, and can be noticed 30 $\mathrm{mm}$ above the sutura squamosa. The grooves run from the coronal suture toward the sutura lambdoidea. In this case a circular erect, slight cranial deformation is suggested in view of the low value of the OGŽ index (84.56).

Nyíregyháza M3,36/c, No. 50

This cranium is that of a 37- to 46-year-old man (Fig. 4). Between the two frontal tubers, a 75-mm $\times 35-\mathrm{mm}$ plain area may be observed, probably due to the usage of some rigid tool (for example, sheet metal or a table made of wood). Although the cranium is classified as the tabular oblique modification because of the observable coronal depression, it can be assumed that the skull may have been modified by applying a double bandaging technique. According to the OGZ index (90.85), medium deformation is suggested.

\section{Nyíregyháza M3, 36/c, No. 61}

This 35- to 55-year-old woman's skull with tabular erect deformation is presented (Fig. 4). The forehead and the nape are plain. On the occipital bone an especially depressed $45 \times 50-\mathrm{mm}$ area was found. The frontooccipital depression was most likely produced by applying some sort of firm instrument (for example, sheet metal or table) fastened with a bandage. The cranium is slightly deformed (OGŽ index 88.67).

Nyíregyháza M3, 36/c, No. 220

This cranium of a 40- to 80-year-old woman is a typical case of the tabular oblique deformation (Fig. 4). A $45 \times$ 42-mm area on the occipital bone can be observed due to the pressuring procedure carried out using a sort of rigid instrument. The forehead is also flattened and strongly inclined. The skull is medium deformed (OGŽ index 92.63).

\section{Discussion}

The appearance of artificial cranial deformation in Europe and the Carpathian Basin was probably related to the movements of the Huns. It seems feasible that the practice of this custom was coextensive with the Hun migration. The data that are known suggest that certain
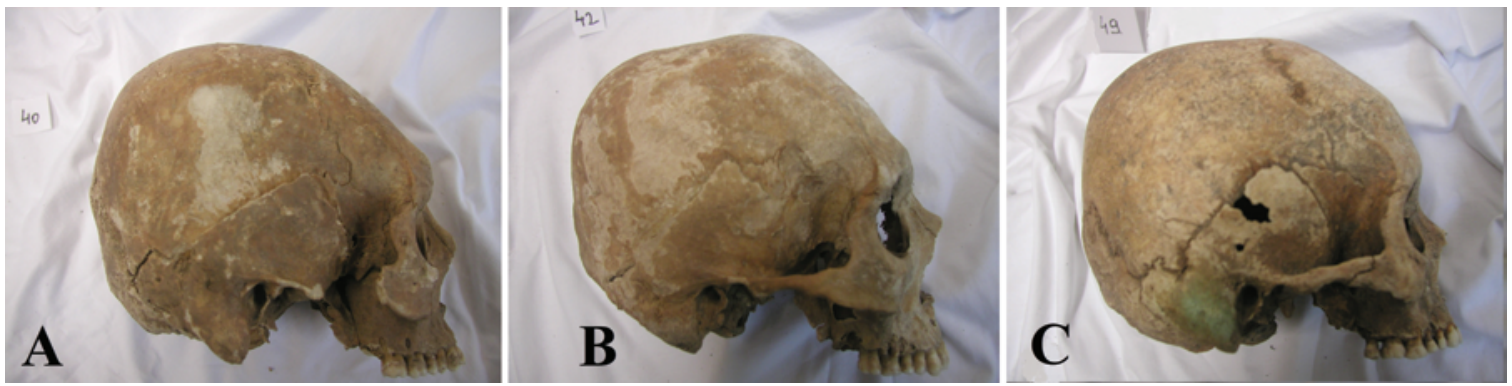

FIG. 3. Photographs showing artificially deformed crania from the Nyíregyháza M3, 36/c site-l: Grave No. 40 (A); No. 42 (B); No. 49 (C). 

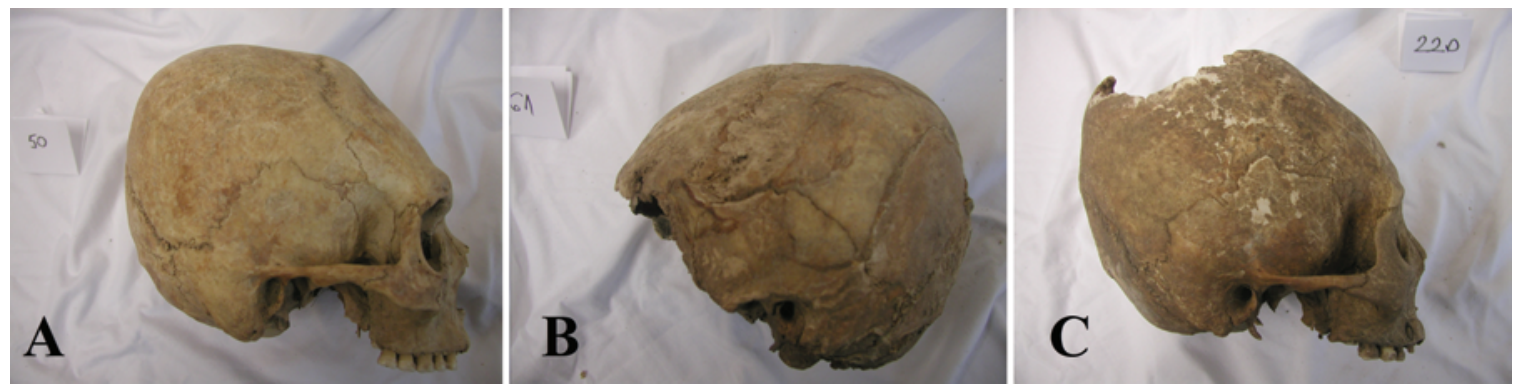

Fıg. 4. Photographs showing artificially deformed crania from the Nyíregyháza M3, 36/c site-II: Grave No. 50 (A); No. 61

(B); No. 220 (C).

elements of the Hun population came into contact with Alan-Turkish peoples, which were in the habit of performing cranial deformation in the area of the present-day Tajikistan. ${ }^{23}$ Thus, the Huns can only be considered to be the transmitters and not the developers of this tradition. The custom of intentional head shaping was actually a "fashion wave" in the Eurasian steppes, which spread to Central and Western Europe. ${ }^{17}$ This custom might have enhanced the social status of individuals and became a sign of ethnicity in Central Europe. It is conceivable that the Germanic peoples adopted the habits of the Huns (including intentional cranial deformation) in the first place because they wanted to be integrated into the Hun Empire and adapt to the conquerors in the hope of subsistence and advance. At that time, the German leaders were integrated by the Huns through marriages of convenience and their warriors were allowed to join the Hun army immediately.

The earliest cases of artificial cranial modification in Eurasia date from the Bronze Age (ca. 2000-1000 BC), practiced by peoples of the "Catacomb" culture and by those of southern Turkmenistan. ${ }^{34,38}$ Nevertheless, this custom disappeared in both of these regions and became common again among the nomadic tribes and herdsmen of the Eurasian steppes in the early Iron Age (ca. $700-500 \mathrm{BC}$ ), first reappearing at the delta of the River Syr Darya. ${ }^{38}$ From the time between these two periods, no artificially modified skulls appeared in Eurasian archaeological sites. It is quite feasible that there was no continuity in the practice of head deformation in this region and that the custom of artificial cranial modification might have evolved independently in these two periods. Moreover, recorded cases dating from the Bronze Age and early Iron Age are presumably not connected with intentionally modified crania from the Carpathian Basin (Hungary). The mode of deformation that affects both the frontal and occipital bones of the skull only became widespread in Central Asia in the 2nd-1st century BC.

Considering the chronology of the finds associated with the intentionally modified crania excavated in the Carpathian Basin, the ethnic relations, and the agglomeration points from the east to the west, 6 phases or groups can be distinguished for the purpose of classifying the Eurasian artificial cranial deformation cases (Fig. 5) ${ }^{24}$

\section{Skull Deformation Phases or Groups}

1) Central Asian Group. The probable origin of artificial cranial deformation can be localized in the territory west of the Tien-Shan, in the valley of Talas and in the Pamir Mountains north of that. This center can be dated from the 1st century BC. The group is also called the Kenkol group, which might be associated with the Hiung-nus (Huns). ${ }^{14}$ The feature of this group is the "classical" skull deformation.

2) Caucasus, Volga Region, and Kalmykia Steppe Group. The nomadic peoples of the steppes (Sarmatians, Alans) conveyed the tradition of intentional cranial deformation to the west circa AD 200. The tradition spread through the Hun invasion, which, across the steppes of Kalmykia and along the Black Sea, reached the River Volga and got as far as the mouth of the River Dnieper. At the same time, some groups of these populations spread both south and north of the Caucasus, forming a partly separate group, where the custom of artificial cranial deformation can be detected as late as the 7th century AD. In this phase, the custom was practiced by the Huns, the Sarmatian-Alans, and various ethnically separate Germanic tribes.

3) Danube Basin Group. This group includes the sites of artificially deformed skulls in Central Europe (present-day Romania, Serbia, Croatia, Slovenia, Austria, Slovakia, Hungary, and the Czech Republic). The center was in present-day Hungary, where more than 200 Hun and Germanic (mainly Gepidic) deformed skulls became known, predominantly dating from the 5th to 6th century. ${ }^{17,23,27}$ The extent of deformations varies from the heavily deformed skulls to the slightly deformed crania and, as far as types of deformation are concerned, besides circular modification forms the tabular deformation types are also present. However, within this large area, regional subcenters can also be distinguished.

4) Middle Germanic Group. The Thuringian area can be determined as a single consistent group. A special characteristic of this phase is that all of the intentionally deformed crania excavated here are identified as belonging to females. These deformed skulls show ethnic relation to the Langobards, who were subjugated by the Huns.

5) South and Southwest Germanic Group. A small number of deformed skulls are known from burial sites in both the Bavarian and the Rhenish territories. The ethnic origin of these macrocephalic finds is not always clear.

6) Rhone Group. This close and unified group located in the southwest of Switzerland as well as in the east 


\section{Artificial cranial deformations from the Hun-Germanic Period}

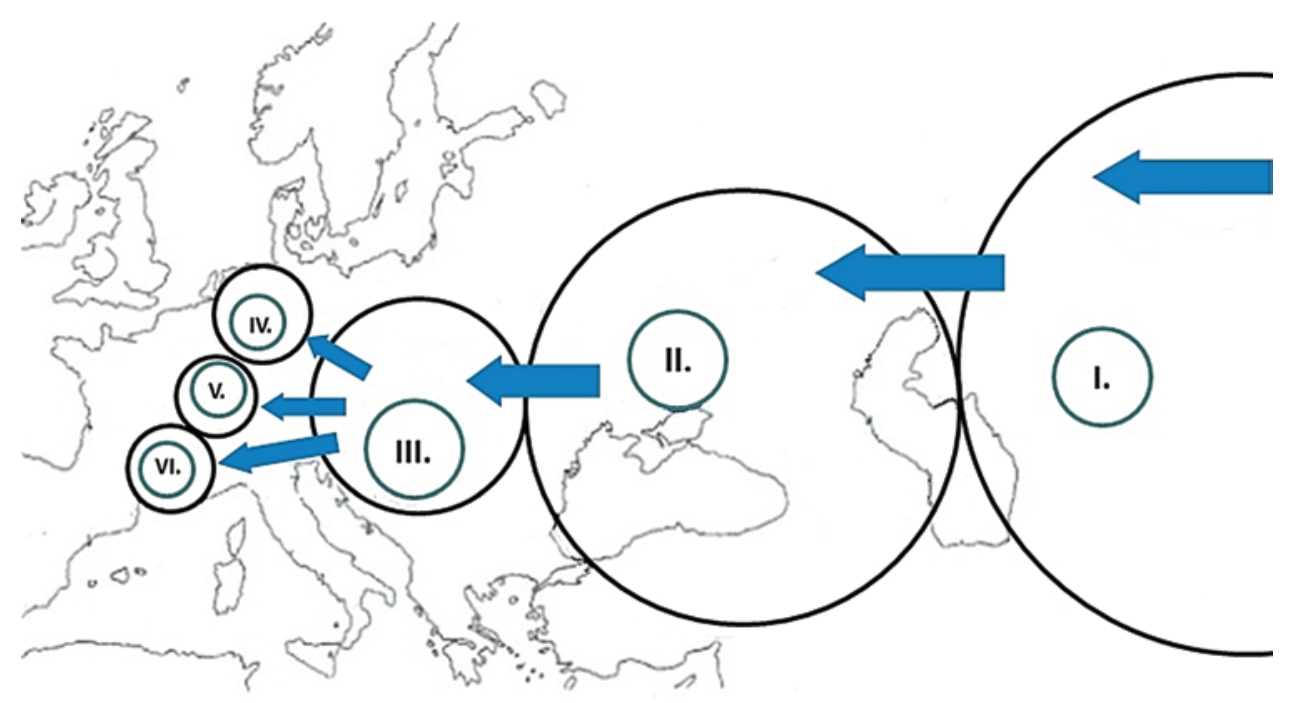

FIG. 5. Map showing the spread of the custom of cranial deformation from Central Asia to Central and Western Europe, in 6 groups or phases. I = Central Asian group; II = Caucasus, Volga region, and Kalmykia steppe group; III = Danube Basin group; IV = Middle Germanic group; V = South and Southwest Germanic group; VI = Rhone group.

of France and the north of Italy, around Lake Geneva and in the valley of the Rhone River is the westernmost group of the Eurasian intentionally deformed cranial finds. The local tradition of skull deformation was practiced by the Burgundians in the early decades of the 5th century, up to $A D 443$. Generally, slightly and moderately deformed skulls are represented in both sexes.

The cranial finds described in this paper belong to the Danube Basin group, the third group mentioned above. The ethnic context of the finds is unambiguous. From an anthropological point of view, all of the individuals manifest the characteristics of the Europid great race, which generally marks the skeletal remains of the common people of Hun and Germanic tribes without any Mongoloid features, whereas these latter traits mainly appear in Hun individuals belonging to the aristocracy, but never in the skeletons of Germanic peoples.

The mode of deformation of the skulls from the Ároktő Csík-gát site is uniform. Because the crania examined showed similar anatomical alterations, they could be classified as a single group, namely the circular erect type. The use of bandaging caused characteristic circular deformation. The values on the OGŽ index were high, which indicated deformations of large extent; that is, the crania could be categorized as hypermacrocranic. Although the OGŽ index of cranium No. 166 could not be measured because of the absence of the splanchnocranium, estimates suggested a medium degree of deformity and the cranium could be regarded as macrocranic. It could also be observed that the age at death of the individuals was relatively young (15-17 and $21-25$ years of age). Artificial cranial deformation occurred in both sexes.

In contrast with the Ároktő Csík-gát burial site, the finds from the Nyíregyháza M3, 36/c cemetery show a wider variety of the types, the techniques, and the extent of deformation. Circular oblique, tabular oblique, and erect types could be distinguished. The use of bandaging was common in this population, with the exception of the cranium in Grave No. 220, which showed no evidence of this usage. In this case, the skull deformation seems to have been achieved using a rigid device, but definitely without a bandage. In a few cases we could observe a flat area caused by one or two hard objects pressed to the frontooccipital surface (Nos. 40, 42, and 61); to the frontal bone (Nos. 40 and 50); or to the occipital surface (No. 220) of the skull. The values of the OGŽ index indicated slightly deformed (Nos. 40, 42, 49, and 61), and medium deformed (Nos. 50 and 220) crania. The age at death was calculated to be relatively higher. Both sexes were represented.

\section{Conclusions}

In the international neurological or neurosurgical literature, studies on Hungarian cranial deformations have not yet been published. Thus, in the present paper we first attempt to shed light on the history, the origin, and the ethnic context of the custom of intentional skull deformation performed in the area of present-day Hungary. The technique used to deform the head and the types of deformations that appeared in the Carpathian Basin (Hungary) are also discussed. Additionally, we offer a morphological description and analysis of 9 artificially deformed skulls dating from the 5th century that were excavated in northeastern Hungary.

As a result of our examinations, we could point out that the cranial finds, both chronologically and ethnically (5th century, Hun-Germanic Period) belonged to the Danube Basin group, which represented the third phase in the Eurasian expansion of the custom of artificial cranial deformation transmitted by the Huns from the east to the west. The skulls were described in detail, considering the mode, the type, and the extent of deformation. Determination of the exact ethnic group to which the individuals belonged was not possible due to the lack of artifacts explicitly referring to either Germanic or Hun 
populations. All 9 of the crania showed the features of the Europid great race, which characterized the common people of both Hun and Germanic tribes on a large scale. There were no sex differences with respect to the modes or types of modification, and deformed crania appeared with both sexes.

Data known from specialized literature ${ }^{17,23,27}$ and our own results equally suggest that the peoples of the Carpathian Basin (Hungary) dating from the Hun-Germanic Period modified their children's skulls frontooccipitally by using bandages and rigid instruments, which resulted in tabular modification forms. The circular types of deformation achieved by applying one or more bandages also seem to have been prevalent (Fig. 6). The intervention changes the normal shape of the head and restricts the development of the cranium in anterior-posterior and/or lateral directions, but permits compensatory growth of the skull-thus the cranial capacity remains constant. ${ }^{6}$ Considering that the custom of artificial cranial deformation was widespread in the Carpathian Basin and might be an indication of the social status of individuals in the 5th-7th centuries, we can assume with good reason that, in the vast majority of cases, this practice should not have caused any neurological disorder or any other serious health problems.

Nevertheless, in a recent paper Józsa and Pap ${ }^{16}$ reported on the morphological similarity of present-day cases of premature ossification disease to artificially deformed skulls from the 4th-6th centuries. Nearly the same abnormal bone changes (small and abnormally shaped sella turcica, vestigial sinus sphenoidalis and sinus frontalis, deformed front skull pit, bigger interorbital space, shallow orbita, deformed and narrow foramen opticum, and impressiones digitales on the bones of skull vault) were
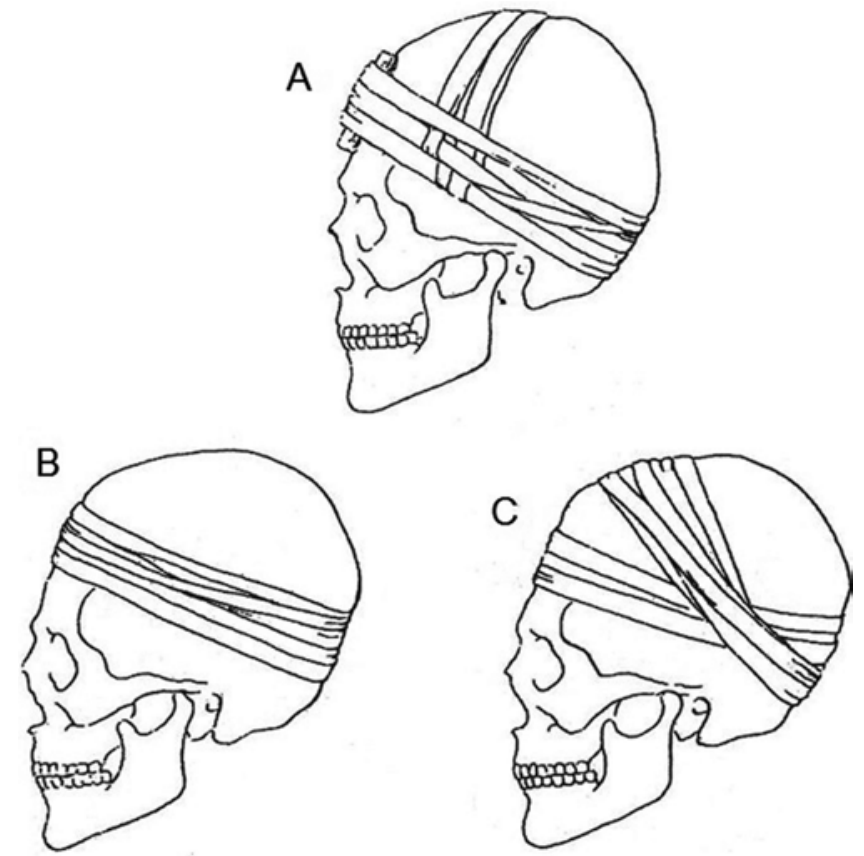

FIG. 6. Drawings showing the techniques of intentional cranial modification used in the Carpathian Basin (modified from techniques published by Kiszely ${ }^{17}$ ). A: Hard instrument pressed by a bandage. B: Simple bandaging. C: Double bandaging. found in the artificially modified crania examined as the alterations typical of individuals suffering from premature cranial suture ossification (craniosynostosis). Relying on these findings, Józsa and Pap assumed that the ancient individuals with artificially distorted skulls, due to the deformed sella turcica which affected the hypophysis, might have suffered from the various clinical and endocrine symptoms that are typical of persons with craniosynostosis. These symptoms can be as follows: spontaneous nystagmus, blurred vision, deafness due to the narrowing of the external acoustic meatus, short stature, frequent hypothyroidism, adrenal hypofunction, and hypogonadism. However, the majority of these symptoms cannot be examined on skeletal finds deriving from ancient times. Consequently we suggest that such serious health problems may only have occurred with a small number of individuals with artificially deformed crania. It is hardly conceivable that such a custom, which was practiced with a result of long survival by various peoples in different historical ages nearly all over the world, would have been followed as a fashion if the health risks had been serious and numerous.

\section{Disclosure}

István János is supported by the TÁMOP 4.2.4.A/2 project, and the reference to it is disclosed as follows: "This research was realized in the frames of TÁMOP 4.2.4. A/2-11-1-2012-0001 'National Excellence Program-Elaborating and operating an inland student and researcher personal support system convergence program.' The project was subsidized by the European Union and co-financed by the European Social Fund." The authors report no conflict of interest concerning the materials or methods used in this study or the findings specified in this paper.

Author contributions to the study and manuscript preparation include the following. Conception and design: János, Molnár. Acquisition of data: Szúcs. Analysis and interpretation of data: János, Molnár. Drafting the article: János. Critically revising the article: Molnár, Szathmáry. Administrative/technical/material support: Szúcs. Study supervision: Szathmáry.

\section{References}

1. Acsádi G, Nemeskéri J: [History of Human Life Span and Mortality.] Budapest: Akadémiai Kiadó, 1970, pp 113-135 (Hungarian)

2. Almássy K, Asztalos C, Babolcsi A, Gergely B, Istvánovits E, Virag C: [Nyíregyháza-Rozsrétszőlő North of the Nevelős sand mine], in: Kisfaludi J (ed): [Archaeological Investigations in Hungary 2005.] Budapest: Kulturális Örökségvédelmi Hivatal és Magyar Nemzeti Múzeum, 2006, pp 291-292 (Hungarian)

3. Bartucz L: Die Gepiden Schädel des Graberfeldes von Kiszombor. A Szegedi Városi Múzeum Kiadványai 7. Szeged, Somogyi Könyvtár és Városi Múzeum, 1936, pp 1-29 (Hungarian)

4. Buikstra JE, Ubelaker DH, Aftandilian D (eds): Standards for Data Collection From Human Skeletal Remains: Proceedings of a Seminar at the Field Museum of Natural History. Fayetteville: Arkansas Archaeological Survey, 1994, pp 1-205

5. Carod-Artal FJ, Vázquez-Cabrera CB: [Neurological paleopathology in the pre-Columbine cultures of the coast and the Andean plateau (II). The history of cranial trepanations.] Rev Neurol 38:886-894, 2004 (Span)

6. Cocilovo JA, Varela HH, O'Brien TG: Effects of artificial de- 


\section{Artificial cranial deformations from the Hun-Germanic Period}

formation on cranial morphogenesis in the south central Andes. Int J Osteoarchaeol 21:300-312, 2010

7. Dembo A, Imbelloni J: Deformaciones intencionales del cuerpo humano de carácter étnico. Buenos Aires: Humanior, 1938, pp 329-337

8. Durband AC: Artificial cranial deformation in Kow Swamp 1 and 5: a response to Curnoe (2007). Homo 59:261-269, 2008

9. Durband AC: Artificial cranial deformation in Pleistocene Australians: the Coobool Creek sample. J Hum Evol 54:795813, 2008

10. Enchev Y, Nedelkov G, Atanassova-Timeva N, Jordanov J: Paleoneurosurgical aspects of Proto-Bulgarian artificial skull deformations. Neurosurg Focus 29(6):E3, 2010

11. Éry K, Kralovánszky A, Nemeskéri J: Történeti népességek rekonstrukciójának reprezentációja. Anthropol Közl 7:4190, 1963

12. Fancsalszky G: [Germanic people in the Carpathian Basin in the first millennium AD.] A Békés Megyei Múzeumok Közleményei 24-25:255-270, 2003 (Hungarian)

13. Fóthi E, Lőrincz G: [Artificial deformed skulls from the early Avar population of Szegvár-Oromdúlő cemetery.] Anthropol Kozl 41:23-39, 2000

14. Ginzburg VV, Žirov EV: Antropologicseszkije materialii iz Kenkolszkogo katakombnogo moglinika v doline r. Talasz Kirgizszkoj SzSzR. Szbornik Muzeja antropologii i etnografii 10:213-265, 1949

15. Johnston FE: Sequence of epiphyseal union in a prehistoric Kentucky population from Indian Knoll. Hum Biol 33:66-81, 1961

16. Józsa L, Pap I: A töröknyereg elváltozásai torzított koponyákban. Folia Anthropol 11:7-14, 2012

17. Kiszely I: [Graves, bones, people and a person.] Budapest: Püski, 2006, pp 436-450 (Hungarian)

18. Kiszely I: The Origins of the Artificial Cranial Formation in Eurasia From the Sixth Millennium B.C. to the Seventh Century A.D. Oxford: British Archaeological Reports, 1978, p 76

19. Kővári I, Szathmáry L: [Assessment of surviving relying upon the V-IXth century skeletal findings dug up at the location of Ároktő, Csík-Gát.] HOMÉ 42:135-163, 2003 (Hungarian)

20. Kristó G: [History of Hungary 895-1301.] Budapest: Osiris Kiadó, 2006, pp 21-22 (Hungarian)

21. Lenhossék J: Die künstlichen Schädelverbindungen im Allgemeinen und zwei künstlich verbildete makrocephale Schädel aus Ungarn, sowie ein Schädel aus der Barbarenzeit Ungarns. Wien: Wilhelm Braumüller, 1881, pp 1-138

22. Lipták P: Avars and Ancient Hungarians. Budapest: Akadémiai Kiadó, 1983

23. Mende BG: [Historical populations and their diseases.] Budapest: Institute of Archaeology of the Hungarian Academy of Science, 2010 (http://www.archeo.mta.hu/antropologia/ paleopatologia.htm) [Accessed February 14, 2014] (Hungarian)

24. Nemeskéri J: Über den Künstlich Deformierten Schädel von Schöningen, Kr. Helmstedt (5.-6. Jahrhundert). Nachr Niedersachs Urgesch 45:129-154, 1976
25. Nemeskéri J, Harsányi L, Acsádi G: Methoden zur Diagnose des Lebensalter von Skelettfunden. Anthropol Anz 24:7095, 1960

26. Oetteking B: Craniology of the North Pacific Coast. Memoir of the American Museum of Natural History, New York. Volume XI. New York: EJ Brill, 1930, pp 12-31

27. Pap I: Data to the problem of artificial cranial deformation, Part 1. Annls Hist Nat Mus Nantn Hung 75:339-352, 1983

28. Perez SI: Artificial cranial deformation in South America: a geometric morphometrics approximation. J Archaeol Sci 34:1649-1658, 2007

29. Romero-Vargas S, Ruiz-Sandoval JL, Sotomayor-González A, Revuelta-Gutiérrez R, Celis-López MA, Gómez-Amador $\mathrm{JL}$, et al: A look at Mayan artificial cranial deformation practices: morphological and cultural aspects. Neurosurg Focus 29(6):E2, 2010

30. Schijman E: Artificial cranial deformation in newborns in the pre-Columbian Andes. Childs Nerv Syst 21:945-950, 2005

31. Sjøvold T: Tables of the combined method for determination of age at death given by Nemeskéri, Harsányi and Acsádi. Anthropol Közl 19:9-22, 1975

32. Stloukal M, Hanáková H: Die Länge der Längenknoche altslawischer Bevölkerungen unter besonderer Berücksichtigung von Wachstumsfragen. Homo 29:53-69, 1978

33. Török A: [The artificial deformation of the cranium.] Természettud Közl 19:261-265, 1887 (Hungarian)

34. Torres-Rouff C, Yablonsky LT: Cranial vault modification as a cultural artifact: a comparison of the Eurasian steppes and the Andes. Homo 56:1-16, 2005

35. Vaday A, Márkus G, Istvánovits E, Kulcsár V: [The Barbaricum in the Roman period], in: Visy Z, Bartosiewicz L (eds): [Hungarian Archaeology at the Turn of the Millennium.] Budapest: Ministry of National Cultural Heritage, 2003, pp 263-280 (Hungarian)

36. Vida T, B Tóth A, Müller R, Vaday A, Szőke BM: [The migration period], in: Visy Z, Bartosiewicz L (eds): [Hungarian Archaeology at the Turn of the Millennium.] Budapest: Ministry of National Cultural Heritage, 2003, pp 283-315 (Hungarian)

37. Weidenreich F: On the earliest representatives of modern mankind recovered on the soil of East Asia. Bulletin of the Natural History Society of Peking 13:161-174, 1939

38. Yablonsky LT: Necropoli Drevnego Khorezma. Vostochnaya Literature, Moscow, 1999

Manuscript submitted October 11, 2013.

Accepted January 20, 2014.

Please include this information when citing this paper: DOI: 10.3171/2014.1.FOCUS13466.

Address correspondence to: István János, Ph.D., College of Nyíregyháza, Institute of Environmental Science, Sóstói út 31/B, Nyíregyháza, H-4400, Hungary. email: janosi2@zeus.nyf.hu. 